\title{
Teacher Education Experiences: What Can We Learn From Brazil, Portugal, and the USA?*
}

\author{
Graziela Giusti Pachane \\ Universidade Federal do Triângulo Mineiro (UFTM), Uberaba, Brazil
}

\begin{abstract}
This work is part of a project whose objective is to study curricular changes in teacher training programs from a comparative approach. We studied the curriculum of three universities (Harvard University, University of Minho, and Universidade Federal do Triângulo Mineiro [UFTM]) from three different countries (USA, Portugal, and Brazil) in the last two decades. To achieve the goals, in addition to literature review and document analysis, we visited the universities, made observations, and interviewed teachers and students. We used content analysis and comparative education methodologies to analyze data. Results highlighted that: 1. Practice-centered program prevails in American education; 2. A praxis-focused approach is emphasized in Portugal; and 3. There is a pursuit of a historical-critical guidance in Brazil (mainly revealed in teachers' discourses) with strong multicultural trend in current curricular policies. The findings helped us to understand how those three universities make links between theory and practice in the training of their teachers, and drew attention to Harvard Teachers Fellows (HTF) Program for its school practice immersion since the very beginning of the program. Studying those experiences from a comparative point of view can help curriculum planners, higher education managers, and policy-makers devoted to the field of teacher education to develop courses/programs that are neither excessively pragmatic, nor idealized and detached from school routine.
\end{abstract}

Keywords: teacher education, educational policy, curriculum, higher education

\section{Introduction}

This paper is part of a project whose objective was to study curricular changes in teacher training programs from a comparative approach. Our focus was on the training of teachers for the specific contents of basic education (chemistry, biology, history, etc.). We studied the curriculum of three universities in the last 20 years: Harvard University in the USA, University of Minho in Portugal, and Universidade Federal do Triângulo Mineiro (UFTM) in Brazil.

The choice of those universities is not fortuitous. Harvard University is known worldwide for both the important contributions that it has made to the advancement of scientific knowledge, the education of leaders, and the prospective look it always represents. For the purposes of this project, Harvard is also important for the

\footnotetext{
* Acknowledgement: This article brings the results of the project called Curricular Reforms in Higher Education: Teachers' training in a perspective of comparative education, funded by CNPq (National Council for Scientific and Technological Development), and that was carried out between 2014 and 2016.

The original article was presented in the proceeding of The IAFOR International Conference on Education, the IICEHawaii 2017, The Hawai'i Convention Center, Honolulu, Hawaii, USA, January 8-10, 2017 (Published: March 10, 2017, ISSN: 2189-1036).

Graziela Giusti Pachane, Ph.D., professor, Department of Education, Universidade Federal do Triangulo Mineiro (UFTM).
} 
regular processes of curricular changes it performs. Challenging programs, such as the Teacher Education Program (TEP) and Harvard teachers fellows program (HTF) were also reasons to have Harvard as one of the first choices in a study of the nature of the one proposed here.

Universities in Portugal had to undergo a series of changes resulting from the implementation of Bologna Process. In addition, the country maintains important historical ties with Brazil, including the language, which could be very important to identify possible transfers from the Bologna process philosophy to Brazilian universities. University of Minho studied these changes, building important critical references that, in addition to curriculum studies carried out there, offered significant contributions to this project.

In 2007, UFTM started a process to create six licensures, whose pedagogical projects were based on the idea of a general and humanistic education cycle, followed by three years of specialization. These courses were created within the framework of a very specific public policy for federal public institutions-Program to Support Restructuring and Expansion Plans of Federal Universities (REUNI), which has been the object of strong criticism from researchers of higher education, as well as teachers and students.

Literature review involved texts about curriculum, educational reform, teacher education, comparative research, educational policy, and history of education in the three countries we analyzed. In addition to literature review and document analysis, we visited the universities, made observations, and interviewed teachers and students. We used content analysis (Bardin, 2008) and comparative education methodologies (Bray, Adamson, \& Mason, 2007; Manzon, 2011) to analyze data.

Our study was divided into four phases: A detailed analysis of each institution, accompanied by a corresponding bibliographic survey (a case study about teacher education in each institution/country), and a final phase of comparative analysis of teacher education policies, and their impact on the three institutions/countries analyzed.

In the sequence, a brief description of each institution's results as well as the comparative point of view is presented. The results allow us to discuss among other topics, "How those three universities make the balance between theory and practice in the training of their teachers," "the importance of recruiting professors committed to basic education," and "the impact of curricular choices on teachers education."

\section{Data Analysis}

In this part, we analyze the three universities separately, and then, make a short synthesis of the main findings of our project.

The University of Minho (perhaps, all Portuguese universities) seek the integration between theoretical studies and pedagogical practice, in particular during the curricular internship of the masters' degree. Currently, it takes only six months, and culminates in the elaboration of a final paper (thesis). After changes resulting from adjustments to Bologna process, the internship consists mainly in observation of other teacher's practice. Trainees should focus on one aspect of the observed practice, which may include the suggestion and implementation of a project, and writing about it based on the theory studied during the course. The paper is presented to an examination board at the end of the course.

It is important to remark that within the European Higher Education Area (EHEA), students graduate in a field of knowledge (three years), and then, the training for teaching occurs only in masters' degree. It lasts two years and the internship takes place in the second year of the program. As the contact with the practice was reduced (internship used to last a whole year), professors affirmed in their interviews that they try to make a 
movement to articulate theory-practice-theory (the idea of praxis) all the time during their disciplines.

Those disciplines may vary, depending on each master's degree in teaching, but in general, they are focused on teaching and teaching of specific contents (mathematics, history, chemistry, etc.); curriculum and assessment; developmental psychology; school as an organization; educational technologies; special education; and more rarely, on disciplines of humanities (ethics, sociology, pedagogical thinking, etc.).

Our interviewees mentioned theoretical bases of Piaget and the principles of reflective thinking, reflective teacher (for example, Antonio Novoa) to inform their teacher education projects. Consequently, the idea of integration between theory and practice (and more specifically, the idea of praxis) should be fundamental in their teaching programs.

The curriculum of the undergraduate and masters courses are proposed by the Ministry of Education, generally in a centralized way, with some margin for autonomy, so universities can choose a few disciplines to compose their curriculum (for example, electives, etc.). According to our interviewees, opening or closing of courses is directly related to the employability of students, and the university has the autonomy to do so.

From an official point of view, we understand that the comprehension of teacher training-as highlighted above-is centered on strong initial education, focused on a broad domain of main field of the teacher (specific knowledge), in its didactics and epistemology, and in the entry into teaching career with the highest possible qualification (currently, master's degree). There is a concern with the education offered to the future teacher, but it seems to us, only in the two final years of university. At undergraduate level, it is enough to concentrate in the specific content. Thus, students do not gradually build their contact with the school, nor with teaching practice.

In our view, there is a univocal understanding, at least among part of the teaching staff and in the official documents, that teaching of specific didactics is the way to follow in teachers' education. References to Piaget and his epistemology were very frequent during the interviews.

Based on our research (2016), it seems that teacher training courses in Portugal risk becoming eminently theoretical. On this, one of the interviewed professors, Maria Rosa (2016) made an excellent clarification, highlighting the importance of "teachers who prepare other teachers," of their commitment to basic education, their need of knowledge about school reality and their constant effort to make the articulation between theory and practice. She also mentioned the importance of choosing who is responsible for teaching each discipline, considering his/her profile, and the importance to give them the needed time to prepare the disciplines, to prepare for changes, including main curricular changes.

She added that in Portugal in general, they accept the norms and do their best within them. In her words,

Although current situation of internships is not the more adequate, we do everything possible to articulate reflexive thinking, practice, and the studied theory (the conception of praxis) to promote the education of the future teacher.

Different from Brazil or the USA, where there is a lack of teachers, Portugal experiments increasing teacher unemployment. As in other fields, in the future Portugal may become an exporter of well-prepared teachers for other countries, as mentioned by our interviewees. They said that Portuguese population is getting older, and with this situation, the number of basic school students is decreasing. As consequence of this process, no new places for young teachers are opening. Classes of French, for example, are closing and no universities are interested in opening this licensure, because graduates will probably not get a job. 
We observed that teachers are more respected in Portugal than in the other two analyzed countries. Although it cannot be compared to other European states (where it seems to be even more social recognition to their profession), the situation of teachers in Portugal is still better than in Brazil or in the USA.

Morgado (2014, p. 140) emphasized current educational and curricular policies, instead of creating conditions for strengthening professional identity and improving teacher professionalism, on the contrary, it had negative effects, such as overwork, excess of stress, loss of confidence, feeling of incompetence, resistance to change, erosion of the profession, recourse to dissimulate and calculate, strategies to obtain results, and a race for pensions. Based on other authors, including those from other countries, he highlighted "teacher's malaise" that affected teachers in different parts of the globe. Morgado (2014) finally pointed out that, "Many of those aspects came from policies of evaluation of results, with charges that fell directly on the person of the teacher, without paying attention to the complexity of the educational process."

It is interesting to point out that in the year we visited the country, a serious economic crisis shook Portugal. Some students to whom we spoke informally at the university reported that the completion of a college was a source of pride both for them and for their families, as many were failing to keep their kids at university.

The pride was such that they adopted the national costume again called "praxe (jokes made with freshmen)," since it involves much more than just a suit. The national costume is composed by black clothes, with a cape, shoes, and special socks, besides the tricorn (hat of three ends). Previously, it was common only in Coimbra, but it became usual in all universities again.

\section{UFTM in Brazil}

In the Brazilian case study, we highlighted the experience of UFTM. Its licensure courses were created within REUNI, a federal project to increase the number of courses and institutions of higher education in the country, especially outside the main economic centers.

In Brazil, different from the other countries, teacher education is offered in undergraduate level (four-year course), in a licensure course that is offered along with the bachelor's degree. Students usually have a group of contents in the specific area of their choice (physics, geography, languages, literature, etc.), disciplines related to teaching of these contents and disciplines related to the field of education and humanities (sociology, sociology of education, psychology, history of education, didactics, politics of education, etc.). There are a few mandatory components (Brazilian sign language, internship, and others that vary, depending on government decisions), and some established amount of hours for certain groups of components, but universities have flexibility to choose the disciplines to offer.

Those courses of UFTM had special characteristics. One of them was the attempt to implant a one-year course-common cycle, with emphasis on a humanistic, interdisciplinary education, without initial division among courses. This project presented, according to their pedagogical projects, proposals inspired by international experiences.

After less than six years of the beginning of this proposal, common cycle was extinguished and each course followed its way, in a very traditional manner. According to our interviewees, UFTM was not able to accomplish neither the attempt of a humanistic and interdisciplinary education nor a better association between theory and practice during the courses.

The same problem is common in other undergraduate courses of the country (Pachane \& Domiciano, 2012). Except for some specific successful experiences conducted by one or another teacher individually, a 
national program called "Institutional Program of Teaching Initiation (PIBID)" has been highlighted as the privileged space that facilitates effective articulation between theory and practice in the education of future teachers.

In general, teacher education courses in Brazil are more theoretical, with emphasis on the basic areas and research, with a historical separation between theory and practice. Those problems were mentioned not only by our interviewees, but also in the literature about the theme.

There are different sources of theory influences in Brazilian education, from multicultural to traditional technocratic approaches, both in policies and practices. The discourses of teachers and students, and in curricular documents, for example, the pedagogical projects of courses, socio-historical approach frequently appear. Dermeval Saviani $(1980 ; 2000)$ was one intellectual of education that was mentioned a lot, as a reference in the field, as well as Paulo Freire (1970; 1997). Their conceptions were considered as a kind of ideal to be followed, but in the daily life of students, they mentioned to feel a more traditional and conservative practice in the classrooms.

As results of the investigations, we noticed that some of the curricular changes occur in the interest of teachers. They are in the general scenery ruled by legislation, but in close, hostage to teachers' conceptions, their commitment to graduation, to certain conceptions of education in university level, their beliefs and values, and in our specific case, with their commitment or not, to the preparation of teachers for basic education.

Graduates, the school community (teachers, principals, parents, and students) have little or no influence in determining what is taught at the university. When it comes to local processes of curricular definition within a university, theoretical fashions, political ideologies, academic vanities, and infrastructural limitations (including teacher qualifications) are often stronger than a true project of preparing professionals and citizens for action in society. Thus, programs, such as PIBID, which allow greater integration of university students with school, and of school with university, start to offer a training considered more relevant than the course itself, or when carried out, provide greater appreciation of the contents learned in the courses.

Brazilian educational policies are now passing through a series of changes and the future of teacher education, as well as the future of education, is still very unclear for us. As examples, we can mention the fact that high school curriculum changed recently and those changes were object of strong criticism from entirely society. Parameters for teacher training are about to change, too. There are projects of law prohibiting the discussion of themes like religion education or sexual education at school. The study of humanities, ethnical themes and social matters in general is about to be abolished in basic education. There are proposals of laws to arrest teachers who express opinions considered ideological or tendentious (especially in political terms) in the classroom. Thus, in this context, the orientation of education and teachers' education is still not clear for us.

There seems to be an orientation for a traditional and conservative approach, centered in the knowledge of the contents and its methodology. Nevertheless, it is still very early to express assertions for that, because we are exactly in the middle of a process that has been in part implemented (middle school curriculum), but which is daily rejected by society and part of important mass media.

In terms of international influences, it can be said that if they reach education, they get there by indirect means. One example can be the use of problem-based learning (PBL) methodology that entered education field by the training of physicians. When we implement a foreigner model, it is not rare that it is appears misrepresented and incomplete, and due to the need to adapt to our reality, they end up being mischaracterized. We think this is the case with the common cycle. Although borrowed from international experiences that 
worked out, the common cycle was thought by one group to be carried out by other, was installed into a traditional structure, and was carried out by a group of professors who did not reach the university, at the same time, and did not necessarily agree with its proposal. In short, an experience bound to go wrong by the manner, it was implemented.

Maybe when the possibilities of traditional rearrangements made by the now consolidated group of teachers are exhausted, they will conclude for the relevance of an interdisciplinary and flexible curriculum, based on a humanist approach.

We believe those changes depend on maturity, group experience, and experimentation. However, in a scenario of policies that tend to traditional and conservative, it is possible that those ideals never leave the imagination of a group of teachers who struggled to renew higher education pedagogy. Such renovations may also succumb before the eyes of those who see in them only a structure aimed at optimizing work for the purpose of exploiting and making teaching work even more precarious in the face of the stratagems of capital.

\section{Harvard Graduate School of Education-Harvard University in USA}

We can consider American experiences as a counterpoint to the densely theoretical models of teacher training programs we have studied up to here. They are strongly dedicated to practice, to classroom daily matters and to the solution of the quotidian problems of the school and its surroundings. For this reason, they are considered among the most pragmatic models of teacher training and analyzers identify connections with ideas of John Dewey in American educational programs.

In the USA, different levels of teacher shortage cause different levels of requirement for admission into the teaching profession in each state, and as consequence, the existence of a wide diversity of training programs. From distance education, in short term courses to doctorate level programs, the USA live with the need to administrate a very complex system, where the most important pre-requisite for becoming a teacher is passing an examination.

This license is valid for a period of five years and needs to be renewed. Some categories can have only his first initial license, which can be renewed for another five years. Others can have the professional license. Usually the license obtained in one state is valid in a group of others, but there is no national license.

The state of Massachusetts has programs at various levels, from teaching for America, which practically works with lay teachers, to postgraduate programs. Harvard has undergraduate training programs (Undergraduate Teacher Education Program [UTEP]) and two graduate (TEP and HTF) degrees. Teacher training at Harvard is closer to projects, such as PIBID than to regular undergraduate programs in Brazil. This openness to adjustment makes it possible for curricula to be changed at any time when necessary, being attentive not only to legislation and the training needs of students, but also to the local needs of states and schools.

This way, when we interviewed teachers at Harvard, they considered we should amplify our study to other universities in order to "capture” the essence of teacher's education in the USA, because Harvard, and the kind of projects it developed, could be considered the "cherry on top" if compared to the different types of programs developed around the country.

The UTEP is held at the college in its final years, and is considered as a pre-graduation. The HTF is the university's latest program and may replace the TEP.

In this program, the hours of courses are not taken by subjects (generally four or five), and the programs are relatively short (one year or one and a half year). The emphasis is on the teaching methodology of a specific 
subject, which is somewhat similar to what we observe in Europe. There are courses in mathematics, social studies/history, English, and science. They are very attentive to issues of multi-culturalism and the psychological characteristics of adolescence, focusing on classroom conflicts, and schools' relationship with the community, and students' interests and needs.

When we conducted this research, HTF was about to start. The program was planned to begin with a spring semester course and monitored teaching at the Cambridge Harvard Summer Academy (CHSA) at the end of college last semester. Participants then have a further academic year of internship at partner schools across the country. In this period, they have reduced working hours in order to continue their studies and additional training sessions offered by faculty. Such moments are online courses or video conferencing meetings. Students then return to campus to complete the program with one more course and another monitored teaching period at CHSA in the following summer. At the end of this period, they may receive their initial teaching license, provided if they pass the required examinations.

Anyone who wishes can stay and have more disciplines, qualifying for the master's degree at the end of the following summer. Those who integrate full-time teaching (preferably in the same school where they did the internship) will continue to receive orientation and distance training for the first two years of their careers.

Summing it up, students perform the oriented practice from the first semester of their training, concomitantly to the disciplines. Then, they stay another year and a half on the program (one of which working in a public school), and continue to receive support from teachers for two years after the program ends. As an incentive, HTF is free, students receive a salary for their work as teachers and with the accomplishment of other two or three disciplines (only these are paid), and they receive the master's degree.

It is important to note that in the USA, there is no expectation that students will teach for the rest of their lives. Teaching is generally understood as a moment in one's life, which may last a few years, or be the transition to another career or to retirement. Teaching in basic education is also understood as a quite exhausting profession. This way, the follow-up in the initial years of HTF has the intention to avoid the "clash of reality" of the beginning teachers and to make them stay longer—and with less frustration —in the teaching activity. We may say it attempts to avoid (early) evasion of the profession, to improve the quality of teaching work and to minimize burnout.

HTF and TEP have somewhat different structures. After the concomitant offer of both, evaluations will be carried out to show which program is most appropriate, whether both should remain, whether they should be agglutinated and undergo improvements, etc..

In the literature analyzed for the present research, the text that most examines about teachers' education in the USA was the Darling-Hammond's study (2014). Among other aspects highlighted by the author, she pointed out that an important milestone for the changes in American teacher education programs was the State Education Annual Report of 2002 (Darling-Hammond, 2014, pp. 130-131). Noting that the teacher certification system was "broken," the report suggested the need to better prepare teachers' communicative skills, mastery of content, and strengthen contact with schools, eliminating other bureaucratic obstacles. The author further clarifies that in addition to the "No Child Left Behind" Program, the document's proposals were used for some states to suppress the specific professional preparation of teachers, basically requiring the sufficiency test.

Thus, with a lack of professionalization in the career in many parts of the country, we understand the idea of our interviewees that the education offered by Harvard is the "cherry on top" and would be quite distant from the American educational reality. 
Darling-Hammond's study also analyzes researches about the impact of the multiple types of preparation for teaching in the USA in terms of the permanence in the teaching career, teaching efficiency, highlighting some of the characteristics that appear to be qualitative differentials of these training programs. Their results (Darling-Hammond, 2014, pp. 138-139) showed that the differentials of a good training course are:

1. Clear vision of what is a good teaching permeating the whole course and practical experience, creating a coherent set of learning experiences;

2. The existence of well-defined standards of performance and professional practice that are used to guide and evaluate course and practice;

3. A strong core curriculum, taught in the context of practice, based on knowledge of the development and learning of children and adolescents, understanding of the social and cultural context, curriculum, assessment, and (didactic) pedagogy of content to be taught;

4. Supervised practical experiences of at least 30 weeks, and opportunities for the student to teach in each program, experiences that are carefully selected to strengthen what is taught simultaneously in the course and intimately intertwined with it;

5. Use of case studies, research, performance evaluation, and portfolios that relate learning to the problems of daily practice;

6. Specific strategies for confronting pre-established beliefs and assumptions of teachers in training about learning and learners, and learning about different experiences and people;

7. A strong relationship, shared knowledge, and shared beliefs between school and university teachers, to work together on the transformation of teaching, school education, and teacher training.

These are directions that we can notice in Harvard practice, and to a certain extent, also in the experience analyzed in Portugal (especially in disciplines, although the emphasis on practice is not as profound as in the American model). Specific programs in Brazilian context, such as PIBID, also present some of those characteristics, but regular licensures’ are far apart from American experience.

\section{Conclusion}

Results allowed us to reflect about professional identity of teachers, teachers' knowledge, competences, and teaching profession. It opens possibilities of discussions renowned Brazilian and foreign authors (such as Tardif, Perrenoud, Garrido, Pimenta, and Brzezinski), and, in particular with the work of Suze Scalcon (2011).

"What a teacher should know?" and "who he or she should be?" are fundamental questions for the curriculum. They refer to the conceptions that direct the policies and practices of teacher education in each country, and that we briefly presented here.

Regarding international transfers between countries, there are indicators that globalization and international competition influence the three institutions. The economic bias appears strongly in some Brazilian policies and in the Bologna process.

As shown before, we did not find common tendencies in teacher training theoretical orientations in the analyzed countries. As Lima, Azevedo, and Catani (2008) pointed out, Brazil oscillated between dialoguing with the international system, reacting to it or being a shy mix of Harvard and Bologna.

In Europe, Bologna process pushes for post-graduation the only formative exit for basic education teachers. Paradoxically, in the USA, there seems to be a movement towards teacher no need of specific specialization. 
This tendency may occur because of a lack of teachers in some regions.

In Portugal and in Brazil, teachers are expected to have a long career, on the other hand, in the USA, if teachers stay in duty for five years, it is considered a good time. Of course, they are making efforts to avoid teachers to leave the career soon, but they face the fact that some students use teaching as a means to start their professional careers and other people use teaching as a way to maintain themselves while they change careers later in life.

With regard to local decisions on curriculum, the commitment of teachers' trainers to basic education is one of the main factors for the effective training of future teachers also committed to quality of education. If in the daily routine in their classes, professors focus the attention of students and directs them, for instance, to research methodology and motivate them only to go to doctorate, it is clear they will not leave university with the desire to work at basic schools.

In this sense, once again, there is a difference among universities. At UFTM, we noticed a preoccupation with the education of researchers, with education on specific fields. In Portugal, with a theoretical education, with what we may call erudition, possibly connected to practice. In the USA, we notice a preoccupation in solving problems based on research results.

Thus, it calls our attention to the importance of the recruitment of teachers' educators, the existence of institutional commitment to the process of teachers' education (if not regional or national) and of the involvement of community in the construction of the pedagogical plans of the courses.

Those are some of the conclusions of our research. We hope the study can help on the expansion of knowledge and reflections about teacher education, especially to a better articulation between theory and practice in teacher training programs, among many other factors that still need our attention worldwide.

\section{References}

Bardin, L. (2008). Análise de conteúdo (Content analysis). Lisbon: Edições Setenta.

Bray, M., Adamson, B., \& Mason, M. (Eds.). (2007). Comparative education research approaches and methods. Hong Kong, CERC: Springer.

Darling-Hammond, L. (2013). Teacher preparation and development in the United States. In L. Darling-Hammond, \& A. Lieberman (Ed.), Teacher education around the World: Changing policies and practices. New York: Routledge.

Freire, P. (1970). Pedagogia do oprimido (Pedagogy of the opressed). Rio de Janeiro: Editora Paz e Terra.

Freire, P. (1997). Pedagogia da autonomia (Pedagogy of autonomy). São Paulo: Editora Paz e Terra.

Lima, L. C., Azevedo, M. L. N., \& Catani, A. M. (2008). O processo de Bolonha, a avaliação da educação superior e considerações sobre a universidade nova (Bologna process, higher education assessment, and issues on the new university). In J. Dias Sobrinho, D. Ristoff, \& P. Goergen (Eds.), Universidade e sociedade (University and society) (pp. 45-72). Sorocaba, S.P.: EdUniso/RAIES.

Manzon, M. (2011). Comparative education: The construction of a field. Hong Kong, CERC: Springer.

Morgado, J. C. (2014). Currículo, identidade e profissionalidade docente (Curriculum, identity, and teacher professionalism). In. J. C. Morgado, \& A. D. Quitembo (Eds.)., Currículo, avaliação, e inovação em Angola (Curriculum, assessment, and innovation in Angola). Benguela: Ondjiri.

Pachane, G. G., \& Domiciano, R. P. L. (2012). Formação de professores das licenciaturas: Panorama das pesquisas sobre licenciaturas no Brasil (Teacher education programs: A panorama of researches about licensures in Brazil). Estudos UCDB (Studies UCDB Journal), 33, 11-21.

Rosa, M. (2016). Interview. In G. G. Pachane (Ed.), Curricular reforms in higher education: Teachers' training in a perspective of comparative education. Uberaba: UFTM: CNPq. (Unpublished report)

Saviani, D. (1980). Do senso comum a consciência filosófica (From common sense to philosophical conscience). São Paulo: Cortez Autores Associados. 
Saviani, D. (2000). Pedagogia histórico-crítica: Primeiras aproximações (Historical-critical pedagogy: First approaches). Campinas: Autores Associados.

Scalcon, S. (2011). A profissionalização pragmática de professores (Pragmatic teacher professionalization). In M. Almeida, \& E. Pereira (Eds.), Políticas educacionais de ensino superior no século XXI-Um olhar transnacional (Educational policies for higher education in the 21st century: A transnational view) (pp. 267-286). St Paul: Campinas-SP. 